\title{
ダンパーブレースを組み込んだ 上路アーチ橋部分構造の動的地震応答実験
}

\author{
森下邦宏 $1 \cdot$ 井上幸一 $1 \cdot$ 川島一彦 $2 \cdot$ 阿比留久徳 $3 \cdot$ 平井 潤 $4 \cdot$ 本田 誠 5 \\ ${ }^{1}$ 正会員 博(工) 三菱重工業（株）広島研究所 鉄構・土木研究室（下730-8642 広島市中区江波沖町 5-1） \\ ${ }^{2}$ フェロー 工博 東京工業大学教授 大学院理工学研究科土木工学専攻（广152-8552 東京都目黒区大岡山 2-12-1） \\ ${ }^{3}$ 非会員 博 $(工$ ） 三菱重工業（株）広島研究所 所長室（下733-8553 広島市西区観音新町 4-6-22） \\ ${ }^{4}$ 非会員 博(工) 三菱重工業（株）広島研究所 鉄構・土木研究室（广730-8642 広島市中区江波沖町 5-1）

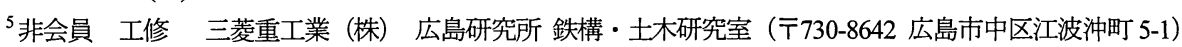

\begin{abstract}
近年, アーチ橋, トラス橋などの中, 長大橋に対する耐震検討が精力的に行われているが, 而震補強実 施例は少なく, 依然, 検討課題の一つとなっている. 著者らは上路ア一チ橋に対して, 横構, 対傾構斜材 に軸降伏座屈拘束型制震ブレース(ダンパーブレース)を組み込んだ耐震構造を提案し, 解析的に地震応答 低減効果を明確にしてきた. しかし, ダンパーブレースの動的挙動を含めた応答低減効果の実験的㭘証は 実施していない状況にあった. そこで, ダンパーブレースを組み込んだアーチ橋を対象とし, 端橋脚のト ラス構造の縮小模型を製作して動的な地震応答実験を実施した. その結果, 繰返し荷重下におけるダンパ ーブレースの安定したエネルギー吸収特性および解析で予測された通りの地震応答低減効果を確認した.
\end{abstract}

Key Words : damper brace, dynamic test, seismic response test, seismic control countermeasure

\section{1. 緒言}

兵庫県南部地震以降，橋梁の耐震性向上に関する研究 が多くの機関で実施され，比較的小規模な析橋などの耐 震補強は一巡した状態にある. 一方, アーチ橋, トラス 橋などの中, 長大橋に対しても, 検討が実施されている が 1 )3)なと, 複雑な地震忘答性状, 的確な耐震構造立案の 困難さ等により実工事に至った例は少なく ${ }^{4)}$, 依然, 研 究課題の一つとなっている.

橋梁の耐震性向上に対するアプローチとしては, (1) 補強板, 補剛板などによる部材の強度を増加させる方法, (2)構造物自体(例えば橋脚)の塑性変形能力, じん性を利 用してエネルギーを吸収して而震性を向上させる方法, (3)構造物と地盤の縁を切り,入力地震動が直接構造物に 作用しないように構造物の地震応答を低下させる方法 (いわゆる免震化), (4)構造物の中に損傷部材を挿入し, その部材のエネルギ一吸収効果により主部材の健全性 を保って而震性向上を図る方法などがある. 海外では長 大橋の而震補強例として, 先駆的にCaltrans ${ }^{5}$ などに代表 される例が示されているが, 上記(1)〜(3)に示す橋脚, 橋 桁の単純な補強，あるいは，ゴム支承，滑り支承，オイ ルダンパーなどを組み合わせた機構を用いた橋杕の免 震・制震化など, 構造的には一般的な補強, 免震, 制震 工法を採用している例が多い.

近年では, (4)の耐震性向上策が建築分野で積極的に採 用されるようになっており の,7など，実施例も多く報告さ
れている ．橋梁への適用に関する研究成果も幾つか報

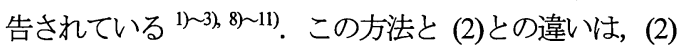
では主部材, 2 次部材自体の塑性変形能力に期待したも のであるのに対し, (4)では主部材は弾性範囲あるいは損 傷がほとんどないレベルに抑えようとする点にある.

著者らは，安定したエネルギ一吸収性能を有する制震 部材として軸降伏座屈拘束型制震ブレース(以下, ダンパ 一ブレース)を提案し, 安定した塑性変形特性, エネルギ 一吸収性能, 塑性変形能力指標を実験的に明確にしてき た ${ }^{12,13)}$. さらに鋼製上路ア一チ橋に対して, 横構や対傾 構斜材にダンパーブレースを組み込んだ而震構造を提 案し, 解析的にその地震応答低減効果を明確にした ${ }^{8) ~ 11) . ~}$ しかし，ダンパーブレースの動的挙動を含めた応答低减 効果の実験的検証は害施しておらず，解析的な検討に留 まっている状況にあった.

そこで本論文では, 動的な作用を含めた地震応答低减 効果を実験的に検証することを目的として, ダンパーブ レースを組み込んだア一チ橋を対象とし, 端橋脚のトラ ス構造の縮小模型を製作して動的な地震応答実験を実 施した結果を報告する. また,震度法(1 次設計)による地 震力を上回る地震力が作用した場合には座屈による耐 力劣化を生じるブレース(以下，座屈ブレース)を用いた 場合の実験も行い,応答低減効果を定量的に示すととも に, ダンパーブレースを組み込むことによる構造物とし ての減衰特性変化についても考察を行う. 

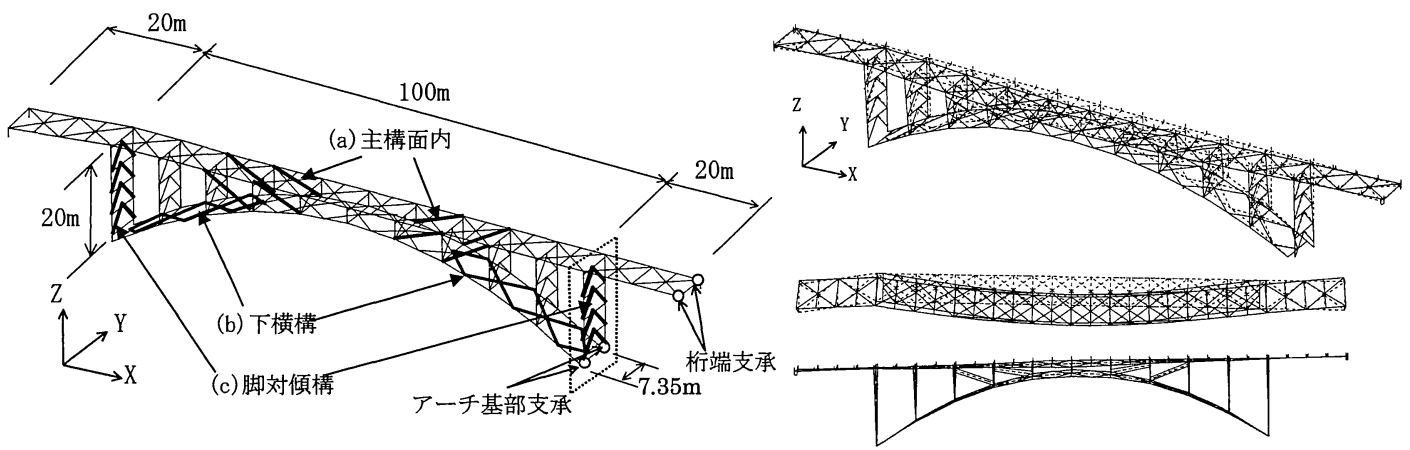

図-1＼cjkstart実橋の構造モデル

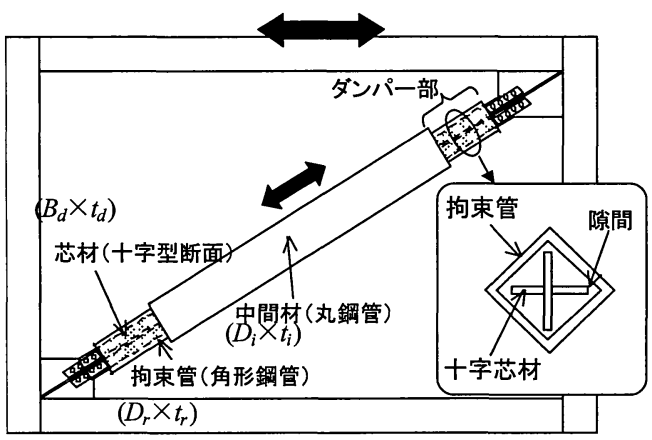

図-3 ダンパーブレースの構造

\section{2. 対象橋梁およびダンパーブレース概要}

\section{(1) 実験対象橋梁}

実験対象橋梁の構造モデル図を図-1 に示す. 対象とす る橋梁は, 橋長 $140 \mathrm{~m}$ (支間長 $20+100+20 \mathrm{~m}$ ), 主構間隔 $7.35 \mathrm{~m}$ の中規模の鋼製上路式ランガー橋であり，平成 2 年度版 道路橋示方書に準じて設計されたものである. 支承条件は，桁端では橋軸方向は可動，橋軸直角方向は 固定，アーチリブ基部ではピン条件で，水平方向につい ては橋軸・橋軸直角方向とも固定となっている. 全質量 は 1,700tonである.

図-1 中には, 文献 8),9)で検討された際のダンパーブレ 一ス配置を太線で示している. (a)の主構面内ダンパーブ レースは橋軸方向対策として, (b)下横構, (c)脚対傾構の ダンパーブレースは橋軸直角方向対策として設置され たものである. 本論文では, 地震入力方向として橋軸直 角方向を対象とするため, 橋軸直角方向の運動に支配的 な端橋脚を抽出して実験模型とするものとした. 図-1 中 には抽出する端橋脚を破線囲みで示す. また, 図-2に本 実験で着目する橋軸直角方向 1 次振動モードを示す.こ の基本固有周期は 1.06 秒である.

\section{(2) ダンパーブレース}

図-3にダンパーブレースの構造を示す. ダンパーブレ 一スは, 鋼材の弾塑性特性を利用した軸降伏座屈拘束型
図-2 実橋の橋軸直角方向 1 次モード(固有周期 $T_{p}=1.06$ 秒)

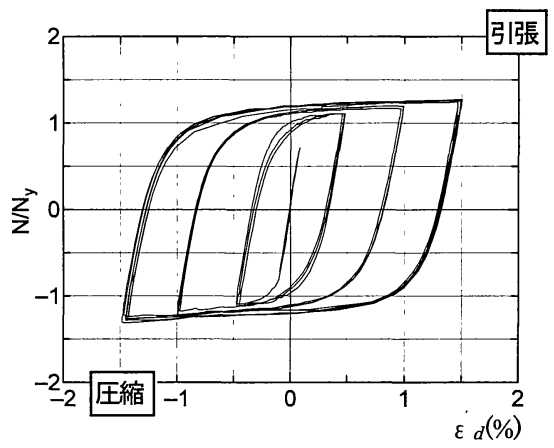

図-4 ダンパー部の履政特性

の履歷ダンパー12),13)である. 建築では一般に，トラス構 造の斜材部分に挿入される. 本実験におけるダンパーブ レース構造は, 作用軸力に対して降伏して弾塑性エネル ギ一を吸収する芯材 (十字型断面: 降伏応力 $\sigma_{y}=235 \mathrm{MPa}$ 級の低降伏点鋼), 芯材と隙間をあけて設置され, 圧縮 力に対して芯材が降伏後に横倒れ座屈, ねじれ座屈する のを拘束する拘束管(角形鋼管)およびブレース部材の両 端に配したダンパー部材(芯材十拘束管)をつなぐ中間材 (丸鋼管)により構成されている. 軸圧縮力に対しては芯 材が降伏後, 軸変形の増加に伴い局部座屈を生ずるが, 拘束管が芯材の局部座屈変形の増大, 横たわみを拘束す ることで, 引張降伏状態と同様に荷重低下の生じない安 定した弾塑性挙動を示す.

図-4 に文献 13)にて実施した繰返し載荷実験結果のう ち, ダンパー部の履歷特性例を示す. 縦軸は軸力を降伏 軸力 $N_{y}$ で除した無次元量, 横軸は平均軸ひずみ $\varepsilon d$ 軸変 位/ダンパー長)であり, 安定した弾塑性エネルギ一吸収 効果を示していることがわかる. 文献 13)では，十字型 断面芯材の自由突出板の幅厚比 $\left(B_{d}\left(2 t_{d}\right)\right)$ をパラメータと した載荷実験を行い，履歷特性の安定性を実験的に求め て幅厚比の制限を設けるとともに, 圧縮／引張で履歷特 性の変化(圧縮時の軸力のへたり現象など)がほとんどな い範囲として許容平均軸ひずみを $1.5 \%$ と設定している. ただし, 実験的にはひずみが $2.5 \%$ に達してもへたり現象 はあるが安定した履歴を描くことは確認済みである. 


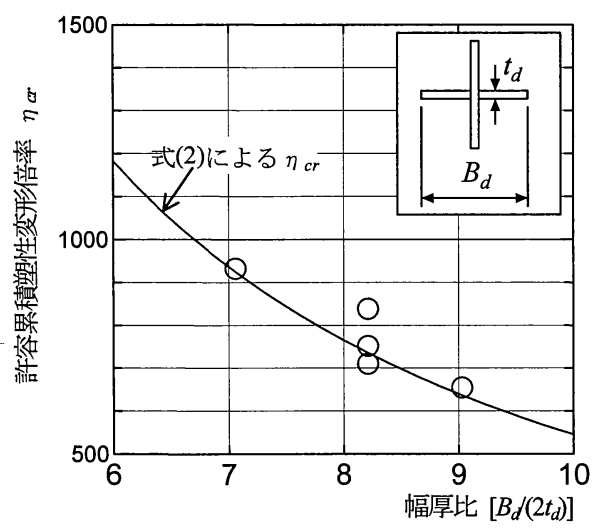

図-5 許容累積塑性変形倍率 $\eta_{c r}$ と幅厚比の関係

図-5にダンパー部分の許容累積塑性変形倍率 $\eta_{a}$ と幅 厚比 $B_{d}\left(2 t_{d}\right)$ の関係を示寸. 累積塑性変形倍率 $\eta$ はダンパ 一の繰返し塑性変形性能を示すものであり次式で定義 される.

$$
\eta=\Sigma \delta_{p} / \delta_{y}
$$

\section{ここで, $\Sigma \delta_{p}=\Sigma \delta_{p^{+}}+\Sigma \delta_{p-}$}

$\Sigma \delta_{p}+$ は圧縮累積塑性変位, $\Sigma \delta_{p}$-は引張累積塑性変 位であり, $\delta_{y}$ は降伏変位である. また, 図中にプロット してある各幅厚比に対する許容值 $\eta_{c}$ は， $\pm 1.5 \%$ 平均軸 ひずみを与えた定振幅繰返し載荷害験において，引張軸 力 $N$ が最大引張軸力 $N_{\text {max }}$ の $95 \%$ まで低下した点を繰返 し変形性能の限界点と見なして求めた值である.

図-5より, 芯材の自由突出板の幅厚比が増大寸るに伴 い，繰返し変形性能は低下寸ることがわかる. 図中には 実験結果に基づき求めた次式による許容累積塑性変形 倍率 $\eta_{a r}$ の推定曲線を示している ${ }^{13)}$.

$$
\eta_{c r}=17800\left(\frac{B_{d}}{2 t_{d}}\right)^{-1.52}
$$

よって, 本ダンパー構造においては, 許容平均軸ひず み $1.5 \%$ 以内の繰返し変形に対して, 式(2)の $\eta_{c r}$ までは安 定した塑性変形能力が確保される.

\section{3. 実験模型}

\section{（1）実橋の縮小模型へのモデル化}

本論文では橋軸直角方向の地震応答を対象とし，この 方向の振動に対して支配的な端橋脚, すなわち柱, 梁と ダンパーブレースで構成されるトラス構造を抽出して 模型化するものとした. また，ア一チ橋の地震応答に対 しては複数の振動モードが連成するが，解析的な検討結 果より, 橋軸直角方向 1 次モードが卓越しているため, 振動特性はこの振動モ一ドに合わせるものとした.

模型化においては, 図-1に示すように, 実構造は4 層 Kブレース構造であるが, 本ダンパーブレース構造の縮 小化における製作限界があるため，これを考慮して2 層

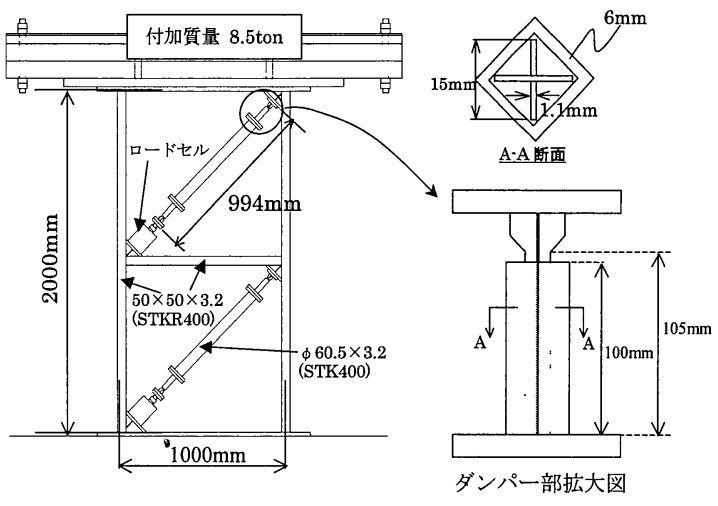

図-6 実験模型(ダンパーブレース組込み構造)

1 ブレース構造にて製作するものとした．さらに，端橋 脚の振動モードは頂部が水平移動する 1 次モードが卓越 するため, マスは模型頂部への集中マスとした. これら を踏まえ，主に振動特性に着目し，次の諸量について実 験模型と実橋で対応しうるようにモデル化を行った.

(1) トラス剛性(ダンパーブレース弾性状態)/ラーメン 剛性(ダンパーブレース塑性化後の状態)の比率 [実 橋で約 $4: 1]$

(2) 端橋脚の卓越振動モードの周期(全体系橋軸直角方 向 1 次モード $T_{p}=1.06$ 秒 : 図-2 参照)

縮小模型(下添え字 $m$ ) と実橋(下添え字 $p$ )の相似則とし ては, 基本物理量の長さ比 $\left(\ell_{m} / \ell_{p}=1 / N\right)$, 密度比 $\left(\rho_{m} / \rho_{p}\right.$ $=M)$, ヤング率比 $\left(E_{m} / E_{p}=R\right)$ の 3 をそれぞれ $N=10, M=10$, $R=1.0$ と設定した. ただし，実験装置の荷重制限，加振 周波数制限などのためRについては相似則の緩和 ${ }^{14)}$ を行 い $R=1.2$ とした. これに基づくとその他の代表的な物理 量比は, 振動数 $f_{m} / f_{p}=3.5\left[=\sqrt{R N^{2} / M}\right]$ (周期 $T_{m} / T_{p}=0.29$ $\left.\left[=f_{p} / f_{m}\right]\right)$, 加速度 $a_{m} / a_{p}=1.2[=N R / M]$, 変位 $\ell_{m} / \ell_{p}=0.1[=1 / N]$, 剛性 $K_{m} / K_{p}=0.12[=R / N]$, 荷重 $P_{m} / P_{p}=0.012\left[=R / N^{2}\right]$ などと なる. よって寸法縮尺比は $1 / 10$ であるので, 実験模型で は高さ $2000 \mathrm{~mm}$, 幅 $1000 \mathrm{~mm}$ とし，上記(1)の剛性比を合 わせるように部材断面諸元の調整を行った. また, 周期 は模型の弾性周期として $T_{m}=0.3$ 秒程度となる.

\section{(2) ダンパーブレース組込み構造模型}

上記(1)に基づき設計した実験模型の概要を図-6 に示 す. 実験模型の高さは $2000 \mathrm{~mm}$ ，幅は $1000 \mathrm{~mm}$ である. 柱, 梁部材は鋼材などの規格寸法上の制限もあるため角 型鋼管 $50 \times 50 \times 3.2 \mathrm{~mm}(\mathrm{STKR} 400)$ を用いた. ダンパーブ レースについては，芯材(エネルギ一吸収部材)が鋼板を 十字型に溶接組立てする構造であり縮尺化が困難であ るため, 削り出し加工により製作するものとし, 製作可 能な寸法として幅 $B_{d}=15 \mathrm{~mm}$, 板厚 $t_{d}=1.1 \mathrm{~mm}$ (自由突出板 の幅厚比 6.8)とした. 材質は実機の低降伏点鋼とは異な るSS400材 $\left(\sigma_{y}=235 \mathrm{MPa}\right)$ を用いた. よって繰返し変形性 


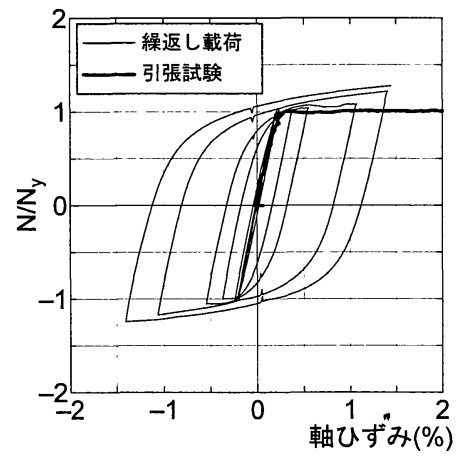

(a)静的漸増載荷試験と引張圾験結果の比較

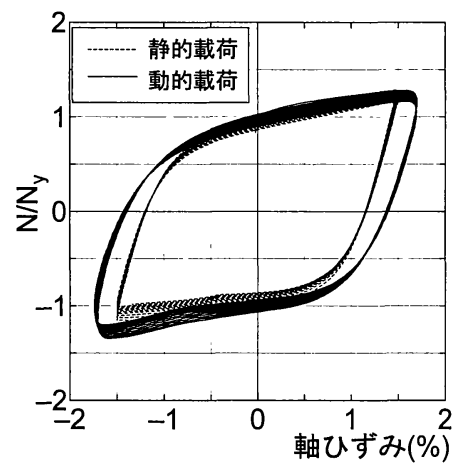

(b)静的，動的疲労載荷試験結果の比較

図-7 芯材要素の履歴特性確認試験結果

能についてはダンパーブレース実機構造より低下する ことが推測される.

また，このように板厚が非常に薄く，幾何学的に算定 した復元力特性と実際の復元力特性の関係に差が生じ ることが想定されるため, 後述する(4)の芯材要素載荷試 験結果に基づき, 降伏軸力は $10.2 \mathrm{kN}$ (1.04tf)とし, ダンパ 一部の軸岡性は $35.3 \mathrm{kN} / \mathrm{mm}(3.60 \mathrm{t} / \mathrm{mm})$ と設定した.

さらに, (1)の11に示すようにトラス剛性とラーメン剛 性の整合性をとる必要があるため, 計測したダンパー部 軸岡性を考慮し，文献 12)の設計条件を満足するように 中間材 (丸鋼管 : $\left.D_{i} \times t_{i}\right)$ は $\phi 60.5 \times 3.2 \mathrm{~mm}(\mathrm{STK} 400)$ を用い た. ダンパー部の拘束管(角形鋼管)については, 芯材模 型寸法に対応する規格品がないため, 芯材の座屈を確実 に拘束できるよう板厚 $t_{r}=6 \mathrm{~mm}$ の板で組み立てた構造と した. ダンパーブレース全体は，両端のダンパー部と中 間材のそれぞれの端部にフランジを溶接し，ボルト接合 にて組み立てる構造とした.

次に, (1)の(2)に示すように周期について実橋端橋脚と 実験模型で整合性をとる必要があるため, 上記構造諸元 に対する剛性を基に, 頂部に設置するマス(質量)は 8.5ton とした. ダンパーブレース組込み模型は 2 体製作した.

\section{（3）座屈ブレ一ス組込み構造模型（震度法設計）}

1 章で示したように，本実験では，ダンパーブレース を組み込むことによる応答低減効果を確認することも 目的としているため, 比較用の模型として, 震度法設計 ( 1 次設計 : $\left.k_{h}=0.2\right)$ のみを満足させ, 大地震時には圧縮座 屈することが想定される座屈ブレースを組み込んだ模 型も製作した. この場合のブレースは $26 \times 26 \times 3.21$ $3.2 \mathrm{~mm}$ の $\mathrm{H}$ 型断面部材とした. 静的座屈軸力は溶接ビー ド断面積なども考慮すると $41.4 \mathrm{kN}(4.23 \mathrm{tf})$ となる. ただし, 上記(2)のダンパーブレース組込み構造模型とは剛性が 異なるため, 弾性固有周期は 0.19 秒となる.

座屈ブレース組込み構造模型は 1 体製作した.

\section{(4) ダンパーブレ一ス芯材要素の履歴特性確認試験}

実験模型のダンパーブレース芯材は幅 $B_{d}=15 \mathrm{~mm}$ ，板 厚 $t_{d}=1.1 \mathrm{~mm}$ の削り出し加工としたため, 実機のダンパ ーブレースと比較すると極端に板厚が薄くなる. そのた め, その履歷特性を要素試験により確認した.

要素試験では, まず単調引張試験を行い，降伏軸力 $N_{y}$ および弾性剛性 $K_{d}$ を求めた. 次に, 別試験体にて繰返し 載荷試験を行い履歷特性の確認を行った. さらに, ひず み速度の影響についても検討するため, 動的な繰返し載 荷試験を行った. 繰返し載荷は変位制御にて行い, 平均 軸ひずみ(軸変位/ダンパー長さ)を片振幅 $0.5 \%, 1.0 \%$, $1.5 \%$ となるように漸増載荷し, その後, 片振幅 $1.5 \%$ で 破断するまで疲労載荷を行う手順とした. 動的載荷では 静的と同様に $1.5 \%$ での繰返しとし，ひずみ速度で $20 \% / \mathrm{sec}$ 程度となるように載荷速度の調整を行った。

図-7 (a)に静的な漸増載荷履歴曲線と引張試験結果の 比較を示す. 縦軸は軸力を降伏軸力 $N_{y}$ で除した無次元量, 横軸は平均軸ひずみ(\%)を示す．これより，図-4 に示す 実機構造と同様に, 圧縮側(一側), 引張側(十側)ともに安 定した塑性変形性状を示すことが確認できた.

また, 図-7(b)に静的, 動的疲労載荷試験の結果の比 較を示す. 動的載荷では装置上の問題から若干目標ひず みを上回ったが, 静的, 動的ともに圧縮/引張軸力の最 大值はほぼ同等であり, 安定した繰返し変形性能を示す ことがわかる. また, 動的載荷の履歷の方が, 振幅が大 きめに出てしまっている影響も含め, 軸力は高めとなっ ている. 文献 15)によれば, 平板型の座屈拘束ブレース 芯材に対しては，ひずみ速度が $20 \% / \mathrm{sec}$ 程度になると復 元力は $20 \%$ 程度増加すると言われているが, 本結果では そこまでの増加は見られない.これは対象とする板厚が 薄いことも原因の 1 つであると考えられる. ただし，こ れらの結果から, 本芯材模型構造でも安定した履歷特性 が得られることが確認できたので，この芯材をダンパー 部構造に組み込み, 地震応答実験を行った. 


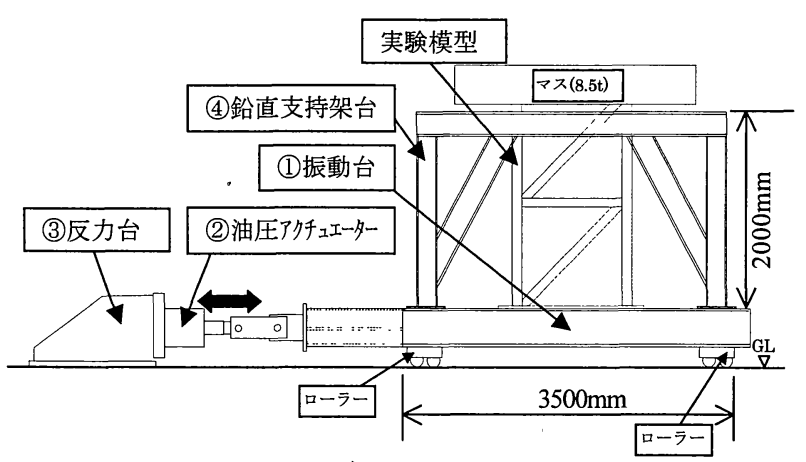

図-8 地震応答実験装置概要

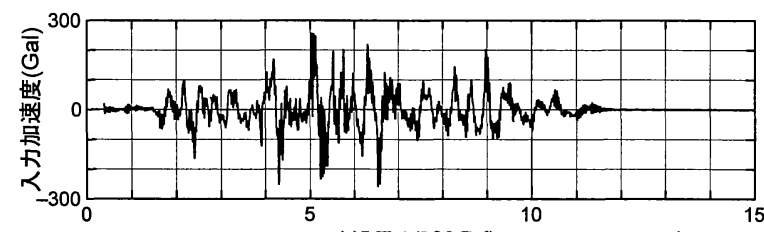

(a)I-II-1(280Gal)

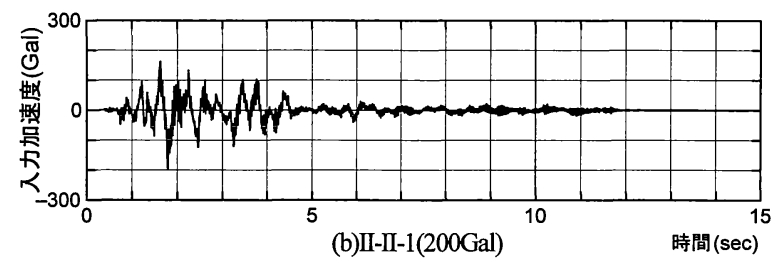

図-9 地震入力波形(実験模型基部計測值)

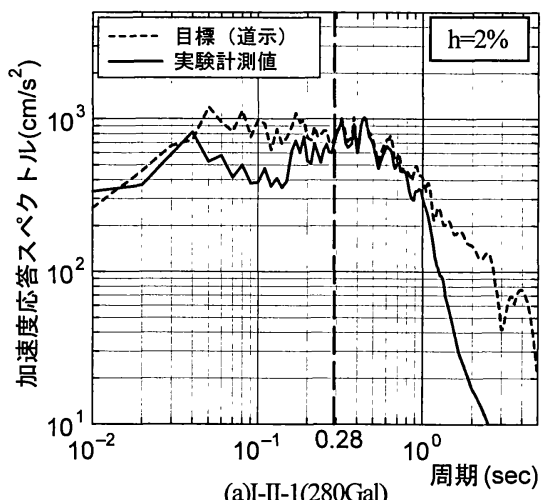

(a)I-II-1(280Gal)

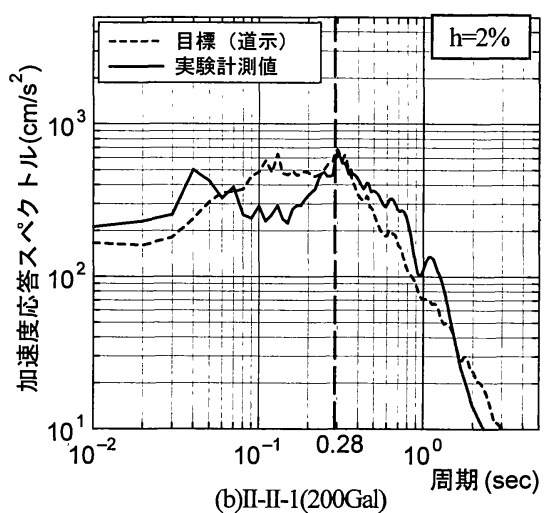

図-10 加速度応答スペクトルの比較

\section{4. 地震応答実験概要}

\section{(1) 実験装置}

実験装置を図-8 に示す，振動実験装置は, (1)実験模型 を設置する振動台, (2)加振用のアクチュエータ $(500 \mathrm{kN})$, (3)クチュエータ用の反力台, (4)模型頂部に載荷するマ スの鉛直方向支持用の架台で構成されている. ここで, 模型頂部マス重量を別架台て鉛直支持したのは，本実験 では水平方向力に対する応答のみに着目したためであ る. 鉛直方向を拘束することで, 水平変位に対して模型 の柱には幾何学的に引張が生じるが, 本実験で想定する レベルの地震入力では，その影響が小さいことを解析的 に確認してあることを注記しておく.また，振動台は低 摩擦のローラーにて支持し, アクチュエータの押引に対 してスムーズに水平方向に可動する. なお，頂部マスも 低摩擦のローラーにて支持するシステムとする.

\section{(2) 計測項目}

実験では，ブレース端部に取り付けたロードセル (50kN 用)にて軸力を, 上層ダンパーブレースの上，下側 のダンパー部に取り付けたレーザー変位計により芯材 の軸変位を計測した. 全体応答としては, 頂部マスおよ び実験模型基部での水平加速度をサーボ型加速度計で
計測し，振動台と頂部マスとの相対変位を鉛直支持架台 とマスの間に設置した変位計にて計測した. また, 柱, 梁の端部などの応力をひずみゲージにて計測した. 動的 な実験となるためサンプリング周波数は $300 \mathrm{~Hz}$ とした.

\section{(3) 入力地震波}

入力地震波としては, 実機対象橋梁の動的設計との整 合性をとるため, 道路橋示方書に示されるレベル 2 地震 動のうち, タイプI 地震動(海溝型地震), タイプII地震 動(直下型地震)の 2 種類を対象とした. 地盤種別として はII種地盤を想定し，道路橋示方書標準波 ${ }^{16}$ の I-II-1 お よびII-II-1の2 波を用いた. ただし，そのままの波形を 入力しても実験模型基部に対する入力が同じ振動特性 とはならないため, 振動台等の伝達関数を考慮した上で 実験模型基部に入力される地震波の振動特性が標準波 のそれと同程度になるように調整を行った. また，次の (4)に示すが，実験では，入力地震波の加速度を調整する ことにより入力地震レベルの調整を行った.

入力地震加速度波形の例として, 実験での最大入カレ ベル時(I-II-1:280Gal，II-II-1:200Gal)に，実験模型基部で 計測した加速度波形を図-9に示寸. また，これらの波形 に対応した加速度応答スペクトルと標準波加速度応答 スペクトル $(h=2 \%)$ の比較を図-10 に示す. 標準波の加速 
表-1 実験ケース

(a)DB1 供試体

\begin{tabular}{|c|c|c|}
\hline & 1 & 2 \\
\hline タイプ & $\mathrm{I}$ & $\mathrm{I}$ \\
\hline 地雲動レベル & $\mathrm{L} 1$ & $\mathrm{~L} 3$ \\
\hline 入力加速度 & 120 & 280 \\
\hline
\end{tabular}

(b)DB2 供試体

\begin{tabular}{|c|c|c|c|c|c|c|c|c|}
\hline & 1 & 2 & 3 & 4 & 5 & 6 & 7 & 8 \\
\hline タイプ & I & I & II & II & II & II & I & I \\
\hline 地震動レベル & L1 & L1 & L1 & L1 & L1 & L2 & L2 & L2 \\
\hline 入力加速度 & 110 & 120 & 123 & 123 & 150 & 200 & 200 & 239 \\
\hline
\end{tabular}

＊地盤種別はすべてП種地盤

*加速度単位は Gal で実験供試体レベル

度応答スペクトルの横軸は, 実験模型レベルに調整して いる. また縦軸は, その最大值を計測結果の最大值に合 わせるように調整している. 図-10 中には, 後述の自由 振動実験結果より得られたダンパーブレース模型の弾 性固有周期 $\left(T_{m}=0.28\right.$ 秒) も示しているが, これより, 本実験で対象とする周波数領域において, 実験での入力 地震波は，標準波の周波数特性を再現できていると言え る.

\section{(4) 実験ケース}

実験では，ダンパーブレース組込み模型を 2 体（DB1 供試体, DB2 供試体), 座屈ブレース組込み模型 (H 供 試体)を 1 体用いた.

表-1 に各供試体の実験ケース, 入力地震波, および実 験模型レベルでの最大入力加速度を示す.ここでは, 地 震動強度レベルを 3 種類（L1，L2，L3）変化させた. こ れらの地震動強度レベルは，2.(1)に示した実機全橋モデ ル解析結果に基づき設定した. すなわち, 実機モデルの レベル 2 地震時の端橋脚頂部の応答変位が $130 \sim 160 \mathrm{~mm}$ 程度であることから, 実験供試体での頂部応答変位の実 機換算值が同程度の場合を L2 地震動(本実験では地震動 最大加速度が 200〜 240Gal 程度の範囲), それより小さい 場合をL1 地震動, それより大きい場合をL3 地震動と定 義した.

よって, DB1 供試体ではタイプ I の L1 地震動が作用 した直後に, L3 地震動が作用した場合の地震応答を想定 し, DB2 供試体ではタイプ I, II $\mathrm{L} 1$ 地震動が連続的 に 5 回作用した後, L2 地震動が 3 回作用した状況を想定 している. H 供試体では, DB1 供試体と同様の状況を想 定している. このような入力手順としたのは, 小さい地 震動(L1)を経験した直後に大地震（L2，L3）が発生した 場合の構造の安全性を確認するとともに, 大小の地震動 が複数回作用した場合の履歴特性の変化を確認するた めである.

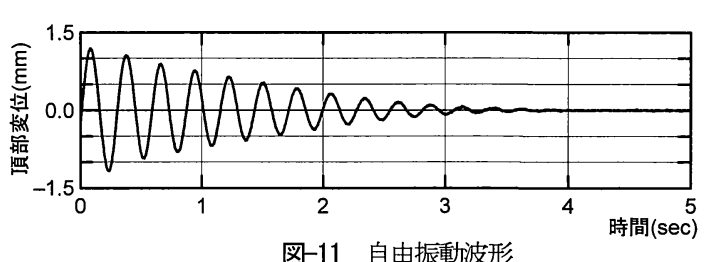

図-11 自由振動波形

\section{5. 地震応答実験結果}

\section{(1) 自由振動実験}

地震応答実験を行う前に，実験供試体の周波数特性， 弾性域における減衰特性を求めるため, ダンパーブレー スの弾性範囲において正弦波加振を行い，加振を急停止

し，その後の自由振動波形を計測した.

自由振動波形の例を図-11 に示す.この波形に対する フーリエ分析より, 実験供試体の弾性固有周期は $T_{m}=0.28$ 秒であった. 目標固有周期は 0.3 秒程度としてい たので，ほぼ予想通りの結果が得られている．また，自 由振動波形より求めた減衰定数は $h=2 \%$ 程度であった.

この減衰定数は以下の検討でも参照する.

\section{(2) タイプ I 地震動に対する地震応答}

地震灾答実験のうち，タイプ I 地震動に対する結果と して, DB2 供試体の 1 回目（I-II-1 : 110Gal [L1 地震動]）, 8 回目 (I-II-1 : 239Gal [L2 地震動]), DB1 供試体の 2 回 目（I-II-1 : 280Gal [L3 地震動]）の3 種類の地震動レベル に対する応答值を図-12 に示す.ここでは, 頂部応答加 速度およひ変位の比較と, 上層ダンパーブレースの上側 ダンパーの軸力一軸ひずみ関係を示している. 応答值は すべて実験供試体レベルの值であり，図-12（c）では， 縦軸は軸力 $N$ を降伏軸力 $N_{y}$ で除した無次元軸力, 横軸 は平均軸ひずみ(\%)を示している.

応答加速度波形を比較すると, L2, L3 地震動入力時 では加速度波形はほぼ一致しているが, L1 地震動入力時 のみ加速度が小さくなっていることがわかる．これは, L1 地震動ではダンパーブレースの塑性化の度合いが少 なく，L2，L3 地震動では同程度に大きく塑性化し，入 カレベルが増加しても，慣性力が増加していないことを 意味している.

頂部応答変位については, 入力レベルの増加に伴い, 大きくなっていることがわかる. 最大応答変位は, L1 地震動で $6.7 \mathrm{~mm}$ (実機換算 $67 \mathrm{~mm}$ ), L2 地震動で $16 \mathrm{~mm}$ (160mm), L3 地震動で $19 \mathrm{~mm}(190 \mathrm{~mm})$ となった。 また, いずれのケースでも, 残留変位はほとんど生じていない. 


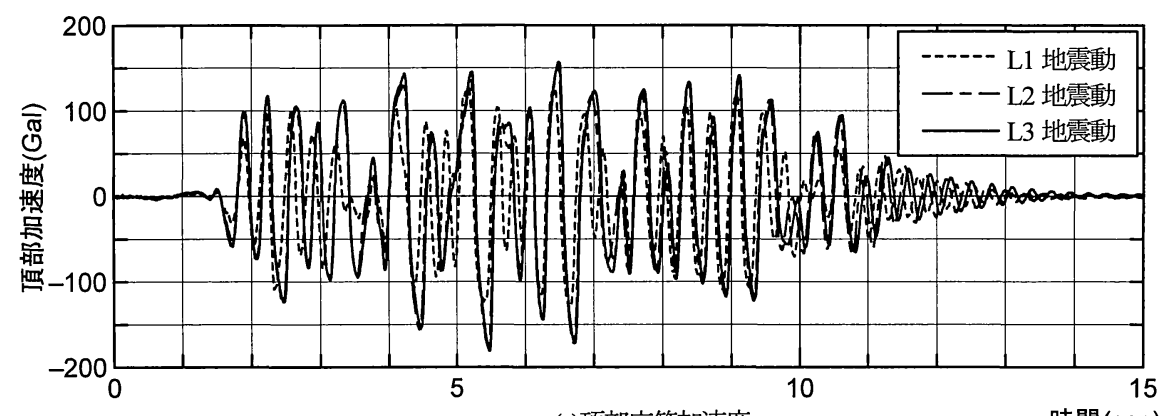

(a)頂部応答加速度

時間(sec)
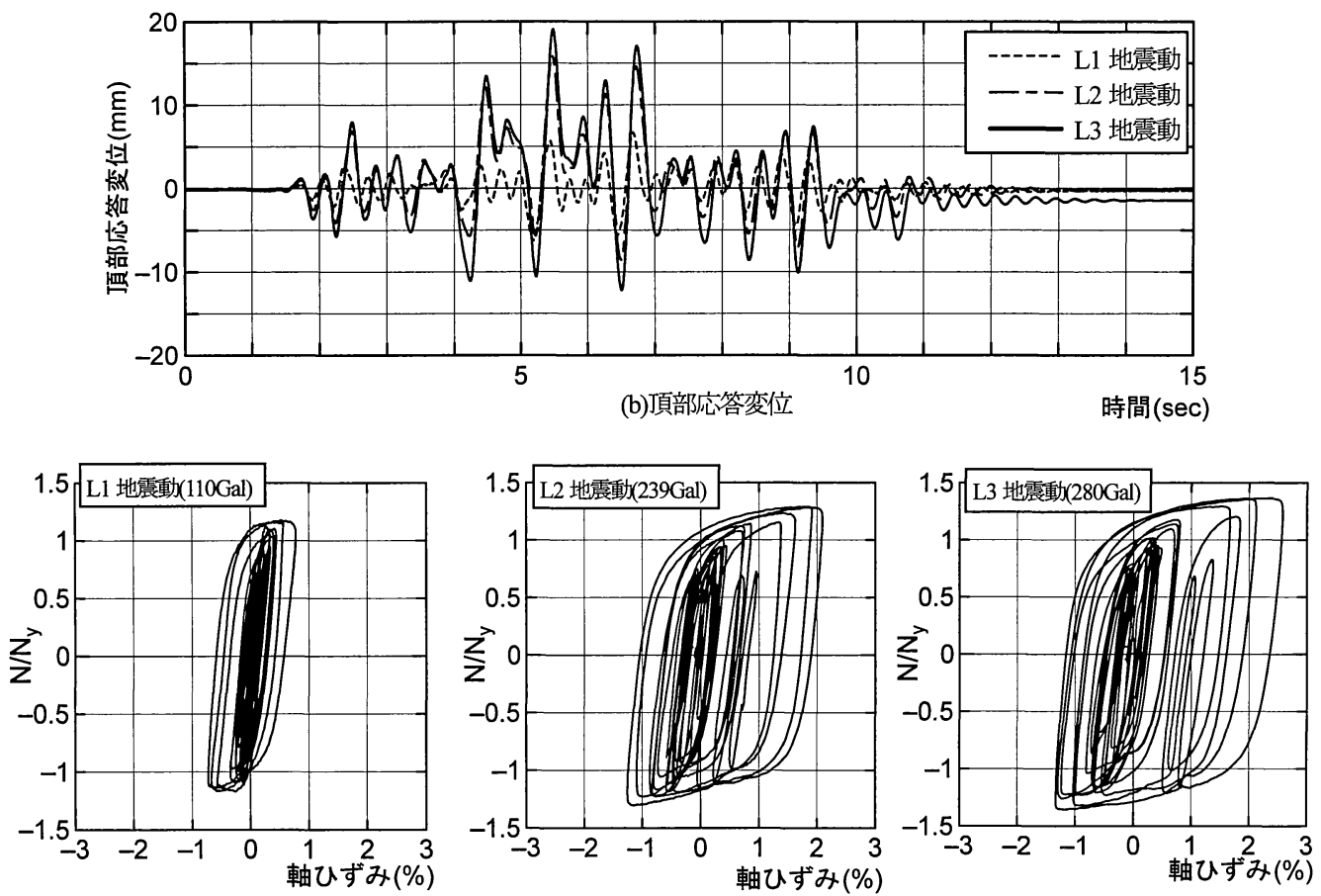

(c)ダンパーの履歴

図-12 タイプ I 地震動に対する応答

ダンパーの履歷曲線の比較からは, 平均軸ひずみは L1 地震動で $0.8 \%$, L2 地震動で $2.1 \%$, L3 地震動で $2.5 \%$ と 入力地震動の強度が増加するにつれて増加するが，2.(2) に示した許容平均軸ひずみ $1.5 \%$ 超えても安定したエ ネルギー吸収性能を有している. 特に L2 地震動の結果 は, DB1 供試体に対する 8 回目の弾塑性応答であるにも 関わらず安定した変形性能を示しており, 十分なエネル ギ一吸収能力を有していることが確認できた.

なお，ダンパーブレース組込み模型を用いたすべての 実験で, 柱, 梁部材端部およびダンパーブレース中間材 などの部材は，模型に貼付したひずタゲージによる計測 結果より弾性範囲内におさまっていた. これは, 実験に おける最大べースシャ（DB1 供試体の 2 回目の実験 : $280 \mathrm{Gal})$ が $15.2 \mathrm{kN}$ であり (6.(1)参照), ラーメンフレー ムの降伏ベースシャ (梁端部で降伏) が $18 \mathrm{kN}$ であるこ
とからもわかる. また，上，下層ダンパーブレースの軸 力時刻歷の比較より, 軸力の差はほとんど生じておらず, 実験供試体は 1 自由度系と見なせる応答を示した.

\section{（3）タイプII地震動に対する地震応答}

タイプI地震動に対する地震応答の例として, DB2 供 試体の 6 回目（II-II-1 : 200Gal [L2 地震動]）に対する応 答值を図-13 に示す.

これらの結果より, タイプ I 地震動に対する応答と同 様に, タイプI地震動に対しても安定したエネルギ一吸 収性能を示していることがわかる。

\section{(4) 累積塑性変形倍率 $\eta$ に関する考察}

次に，地震応答時のダンパー部の累積塑性変形倍率 $\eta$ に関する考察を行う. 図-14 (a)，(b)にDB1 供試体, DB2 


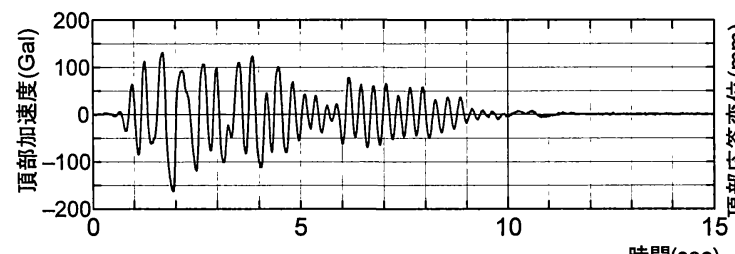

(a)頂部応答加速度

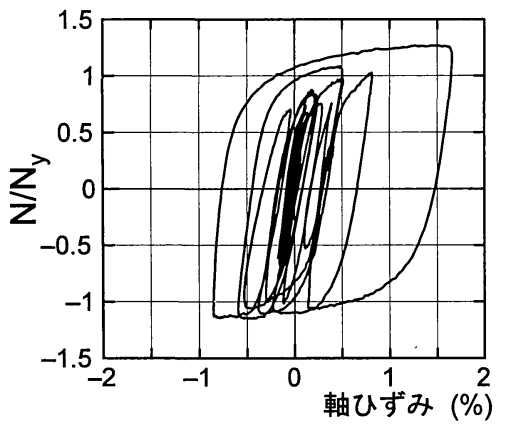

(c)ダンパーの履歴

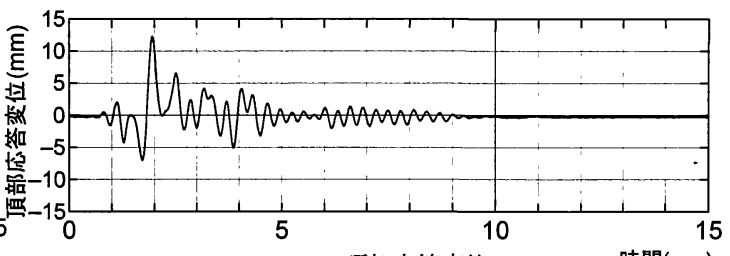

(b)頂部応答变位

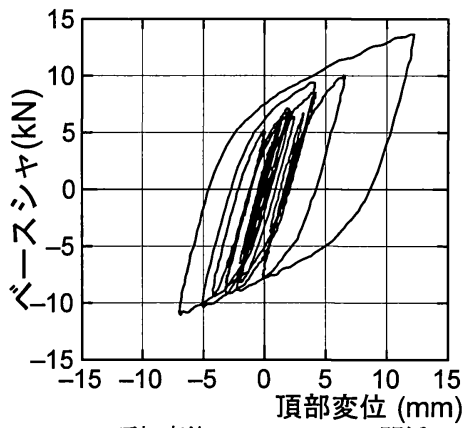

(d)頂部変位一ベースシャの関係

図-13 タイプП地震動に対する応答
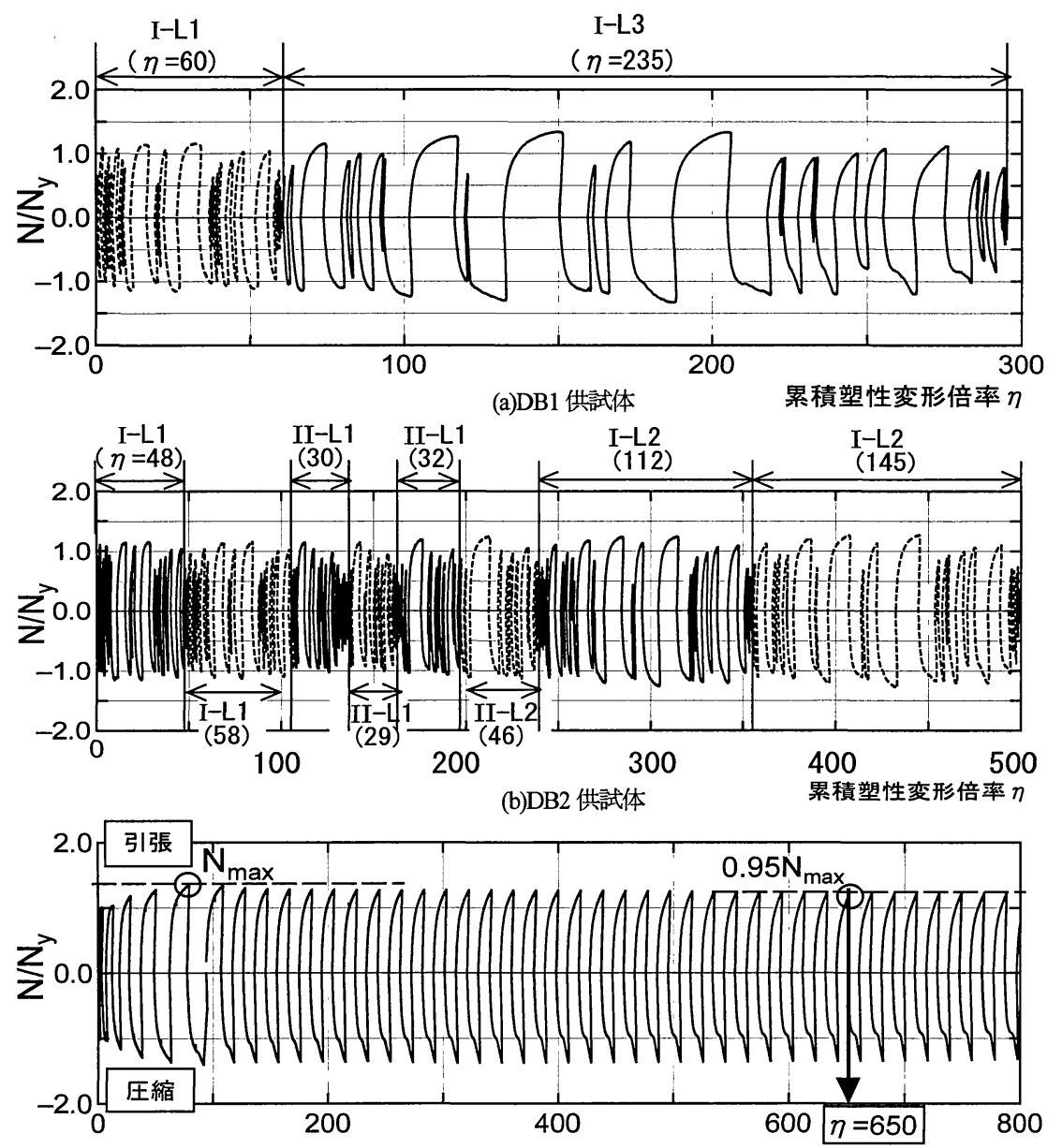

(c)ダンパー部要素試験結果 累積塑性変形倍率 $\eta$ 図-14 累積塑性変形倍率 


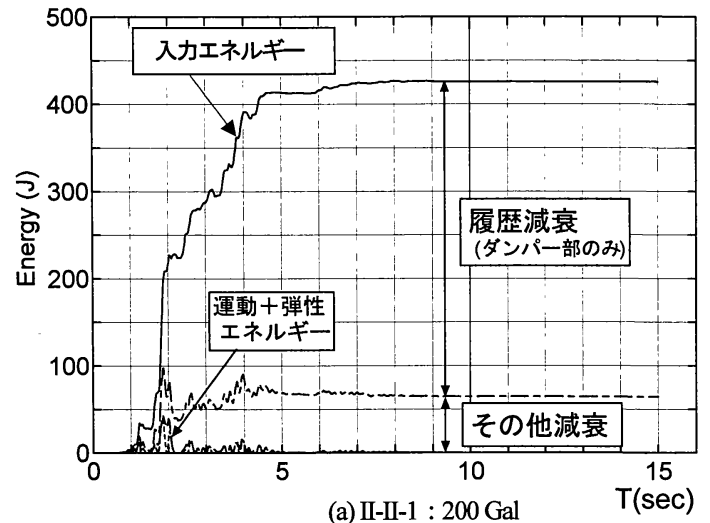

(a) II-II-1 : $200 \mathrm{Gal}$

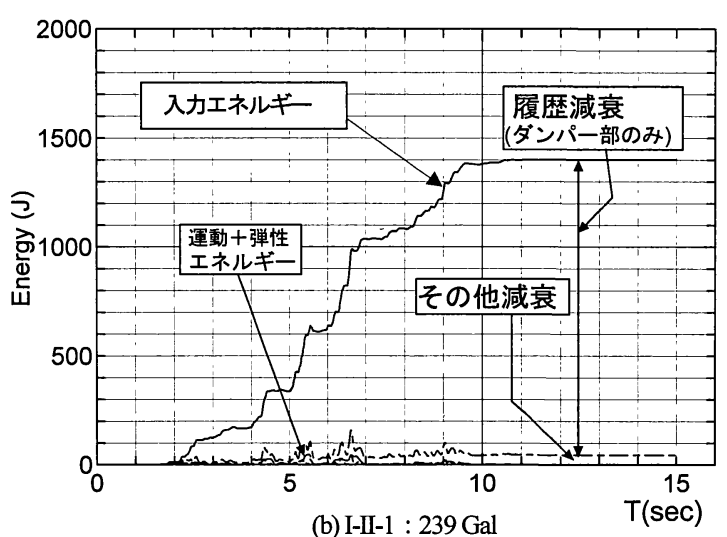

(b) I-II-1 : $239 \mathrm{Gal}$

図-15 エネルギー時刻歷波形

供試体の上層ダンパーブレースの上側ダンパー部の累 積塑性変形倍率 $\eta$ (式(1)より算定) と軸力の無次元量 $N / N_{y}$ の関係を示す. 複数の地震動を作用させているので, そ れぞれの結果を線種を変えて示している. また，図中に 示す各地震入力に対する記号は次例のようである.

\section{I一L1：地震タイプー地震動レベル}

$(\eta=60): 1$ 回の地震応答での累積塑性変形倍率

また，比較のために3.(4)で行ったダンパー部要素の繰 返し載荷試験結果における累積塑性変形倍率と無次元 化軸力の関係を図-14(c)に示す.

図-14(c)の結果より, 実機構造と同様に, 本ダンパー 模型（幅厚比 6.8）に対する許容累積塑性変形倍率を軸 力 $N$ が最大軸力 $N_{m a x}$ の 95\%まで低下した点として評価 すると， $\eta_{c r}=650$ と評価できる. また, 式(2)に示す推定 式を用いると, 幅厚比 6.8 に対しては $\eta_{a r}=900$ 程度と推 定できる. 実験結果の $\eta_{c r}$ の方が小さい值となっている のは, 鋼材が一般鋼であるSS400材を使用していること， 板厚が実機に比べ薄いことなどが原因と考えられる.

次に, 図-14(a)，(b)より，各地震動入力レベルごと に累積塑性変形倍率を評価すると, 地震動タイプによっ て異なるが, L1 地震動では $\eta=30 \sim 60$ 程度, L2 地震動 で $\eta=50 \sim 145$ 程度となり, L3 地震動では $\eta=235$ にも達 した. 地震動タイプ別に見ると, DB2 供試体の結果より, 同じ L1 地震動でもタイプ I 地震動作用時の累積塑性変 形倍率の方がタイプII地震動作用時の 2 倍程度となった。

また，各供試体ごとの実験終了時における累積塑性変 形倍率は, DB1 供試体で $\eta=300$ (最大平均軸ひずみ $2.5 \%$ ), DB2 供試体で $\eta=500$ (最大平均軸ひずみ $2.1 \%$ )であった. これらはダンパー模型の許容累積塑性変形倍率 $\eta_{a r}=650$ 以下となっており，それに対応して，実験終了時には芯 材は破断せず耐力を保持していた. しかし $\eta_{c r}=650$ は, 平均軸ひずみ土 $1.5 \%$ の定振幅繰返し変形に対する許容 值として定義されたものであることを踏まえると，本実 験では芯材の耐力は安定していたが, DB1 供試体のよう な大ひずみを経験した場合, 芯材の局部座屈の進展が早
くなり, 所定の繰返し変形性能まで達さない可能性は十 分に想定されるので注意が必要である.

\section{(5) エネルギ一応答に関する考察}

地震応答実験結果のうち, DB2 供試体の 6 回目 (IIIII-1 : $200 \mathrm{Gal}$ [L2 地震動]), 8 回目 (I-II-1 : $239 \mathrm{Gal}$ [L2 地震動]）におけるエネルギ一時刻歴を図-15(a), (b) に示す. ここで, 入力, 運動, 弾性, 塑性履歴のそれぞ れのエネルギーは，本実験模型がほぼ 1 自由度系と見な せる応答を示していることを考慮し，文献 17)を参考に 次式に基づき算定したものである.

$$
\begin{array}{ll}
\text { 入力エネルギー } & \int_{0}^{T}\left(-m \ddot{y}_{0}\right) \dot{y} d t \\
\text { 運動エネルギー } & m \dot{y}^{2} / 2 \\
\text { 弾性エネルギー } & K_{F} y^{2} / 2 \\
\text { 塑性エネルギー } & \sum N(\delta) \cdot \Delta \delta_{p}
\end{array}
$$

その他の減衰エネルギー 式(3)-\{(4)+(5)+(6)\} (7)

ここで, $m$ は 1 自由度系と見なした場合の一般化質量 で解析的に算定した值(約 8.5ton), $K_{F}$ は柱, 梁のラーメ ン構造の弾性剛性， $\dot{y}$ は頂部マスの相対速度，yは頂部 マスの相対変位, $N(\delta)$ はダンパー軸力, $\Delta \delta_{p}$ はダンパ 一塑性軸変位増分, $\ddot{y}_{0}$ は地震入力加速度である.

入力エネルギーを見ると, タイプI地震動に対しては 地震入力後の 2 5 秒で急激に最大値に達する直下型地 震の特徵的な傾向を示しているが, タイプ I 地震動に対 しては, 約 10 秒で最大值に達している. 次に, 吸収エ ネルギー分担率に着目すると, タイプ【地震動作用時に は全体吸収量の $84 \%$ をダンパーブレースで吸収し, 残り の 16\%をその他の減衰効果にて吸収している. タイプ I 地震動作用時についてはさらに顕著であり，95\%をダン パーブレースで, 残りの 5\%をその他の減衰効果で吸収 している. これは, 水平力に対してダンパーブレースの 軸変形によって抵抗する構造であるためであるが, 次に 示す 5.(6)の減衰特性の評価からも, 実験供試体構造にお ける等価减衰定数 $h_{e q}$ は $15 \%$ 程度以上と推定されること, 


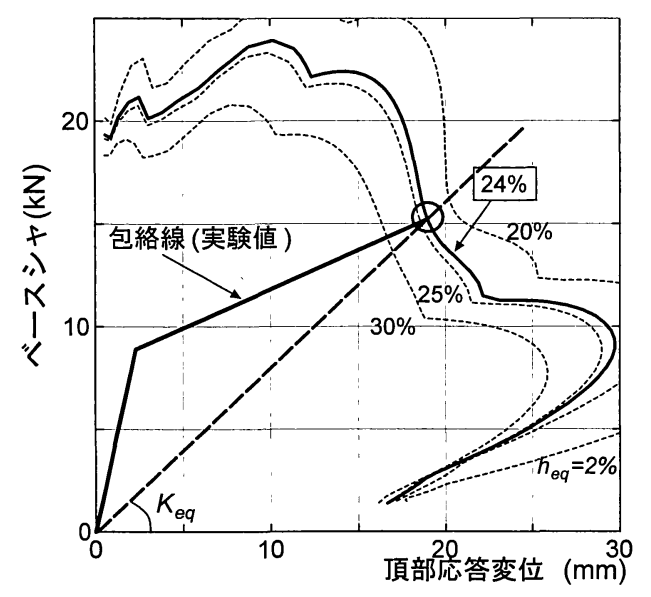

図-16 実験結果と等価線形解析による応答値の比較

5.(1)で行った自由振動実験から得られた弾性域における 構造减衰が $h=2 \%$ 程度であることなどを踏まえると，こ の結果は妥当なものであると言える. なお，タイプIの L3 地震動を入力した結果(DB1 試験体2回目)においては, 全体エネルギーの 96\%をダンパーブレースで吸収し， 4\%がその他の減衰で吸収される結果となった.

\section{(6) 減衰特性の評価および考察}

次に, ダンパーブレース組込み構造の減衰特性に関す る検討として，等価減衰定数の定量的な評価を試みた. ここでは，等価線形解析の考え方を用いて評価を行った.

一般に応答スペクトルを用いた等価線形解析 ${ }^{177 て ゙ は, ~}$ あらかじめ構造の骨格曲線, およひ塑性率 $\mu$ の関数とし て等価減衰 $h_{e q}$ の評価式を決めておく. 次に, 初期の応 答值 (塑性率) を仮定して, 等価剛性 $K_{e q}$ 等価周期 $T_{e q}$ ), 等価減衰 $h_{e q}$ を算定し, それに対応した応答スペクトル $S\left(T_{e q}, h_{e q}\right)$ における応答值を求めて初期の仮定值との比較 を行う. 仮定值と算定值が一致しない場合には, 算定值 を初期值として一致するまで収れん計算を繰り返す. 算 定された応答值はあらかじめ決めた骨格曲線上に乗る.

しかし，本ダンパーブレース構造における塑性率 $\mu$ と 等価減衰 $h_{e q}$ の関係式は明確ではない. そこで, 固有周 期, 減衰定数をパラメータとした 1 自由度系モデルに対 するパラメトリックな弹性地震応答解析を実施して, 解 析結果の最大值と実験結果の最大值との比較を行い, 結 果が一致する弾性态答に対する減衰定数を求め, それを 等価減衰定数 $h_{e q}$ として評価した.

その評価の一例として, DB1 供試体の L3 地震動(タイ プIに対する推定結果を図-16 に示す. 図は横軸に頂部 応答変位, 䌐軸にベースシャ（頂部質量 $\times$ 頂部加速度） を示す. 図中には, 実験における頂部応答変位一ベース シャの包絡線を太実線で示し, 最大值を○印で示す. ま た, その最大值と原点を結ぶ太破線は等価剛性 $K_{\text {eq }}$ を示 しており, 各減衰定数の応答曲線と太破線の交点は, 同

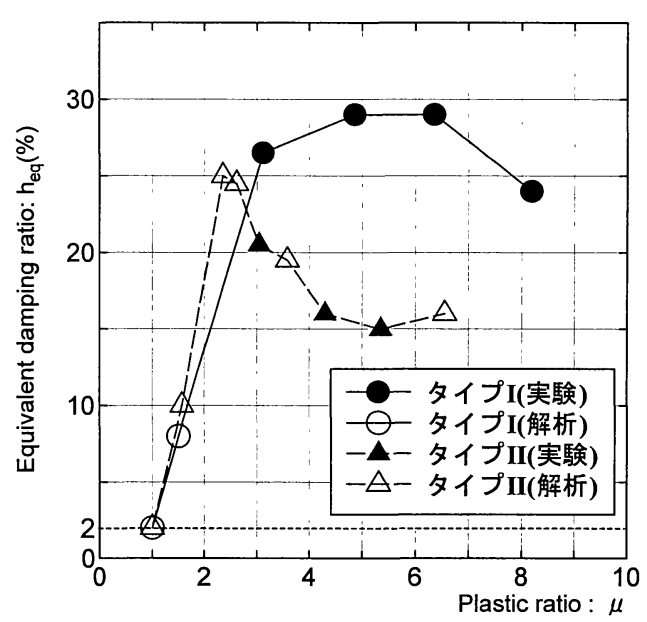

図-17 塑性率一等価减衰定数の関係

表-2 等価減衰定数の評価結果

\begin{tabular}{|c|c|c|c|c|c|}
\hline タイプ 地震動 & $\begin{array}{c}\text { 最大加速度 } \\
\text { レベル }\end{array}$ & $\mu$ & $h_{e q}(\%)$ & 備考 \\
\hline I & L1 & 60 & 1.50 & 8.0 & 解析結果 \\
\hline I & L1 & 120 & 3.12 & 26.5 & DB2(1回目) \\
\hline I & L2 & 200 & 4.87 & 29.0 & DB2(7回目) \\
\hline I & L2 & 239 & 6.36 & 29.0 & DB2(8回目) \\
\hline I & L3 & 280 & 8.19 & 24.0 & DB1(2回目) \\
\hline
\end{tabular}

\begin{tabular}{|c|c|c|c|c|c|}
\hline タイプ & $\begin{array}{c}\text { 地震動 } \\
\text { Lベル }\end{array}$ & $\begin{array}{c}\text { 最大加速度 } \\
(\mathrm{Gal})\end{array}$ & $\mu$ & $h_{e q}(\%)$ & 備考 \\
\hline II & L1 & 60 & 1.57 & 10.0 & 解析結果 \\
\hline II & L1 & 100 & 2.35 & 25.0 & 解析結果 \\
\hline II & L1 & 115 & 2.61 & 24.5 & 解析結果 \\
\hline II & L1 & 127 & 3.04 & 20.5 & DB2(4回目) \\
\hline II & L2 & 140 & 3.58 & 19.5 & 解析結果 \\
\hline II & L2 & 150 & 4.30 & 16.0 & DB2(5回目) \\
\hline II & L2 & 200 & 5.35 & 15.0 & DB2(6回目) \\
\hline II & L3 & 230 & 6.55 & 16.0 & 解析結果 \\
\hline
\end{tabular}

一の等価剛性(等価周期)に対する応答值を意味する.こ の図より, 最大応答值にほぼ一致する応答スペクトルは, 減衰定数 $h_{e q}=24 \%$ の結果であり, これがこの地震応答に おける等価減衰定数と評価できる. これより，5.(1)に示 すように構造减衰が $h=2 \%$ 程度であれば, ダンパーブレ 一スを組み込むことにより， $\Delta h=22 \%$ の減衰が付加され ていることになる.

また, 表-1に示した実験ケースのうち, 各地震入カレ ベルに対する等価减衰定数 $h_{e q}$ の評価結果を表- 2 に示す. 表-2 には各実験での頂部応答変位一ベースシヤ関係よ り読みとった塑性率 $\mu$ も示す. さらに, 図-17 にこの塑 性率 $\mu$ と等価減衰定数 $h_{e q}$ の関係を示寸. 図中の印は夕 イプI 地震動に対する実験結果の評価を， II 地震動に対する実験結果の評価を示している.ただし， 図-17 のタイプII 地震動に対する評価のように, 実駼結 果の評価のみでは, 点数が少なく塑性率と等価減衰定数 の相関性がつかみにくいので, 文献 11),19)に示寸解析モ デルを用いた地震応答解析を実施し，その結果を用いて

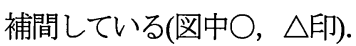


これらの結果より, タイプI 地震動については，定常 応答に対する等価減衰評価 ${ }^{17)}$ と同様に, ある塑性率で最 大の減衰を示し, それ以降は減衰が減少する傾向を示し ている. その際に, 塑性率 $\mu=3 \sim 8$ 程度の範囲では等価 減衰定数 $h_{e q}$ は $20 \%$ 以上となっている. 一方, タイプ II 地震動については, 実験結果のみでは塑性率 $\mu$ と等価減 衰定数 $h_{e q}$ の明確な相関性が得られなかったため, 複数 の解析結果で補間を行った. その結果, 塑性率 $\mu=2.5$ 程 度までは $h_{e q}$ は増加するが, 塑性率 $\mu=2.5 \sim 4$ の範囲では $h_{e q}$ は減少し, 塑性率 $\mu=4 \sim 7$ の範囲では $h_{e q}=16 \%$ 程度で 一定となっており, タイプI地震動とは異なる傾向を示 した.これは地震動のタイプ, とりわけ繰り返し数, 継 続時間などの違いが原因であると考えられるが，この傾 向を明確にするためには，さらに多くの地震動に対する 検討が必要である. ただし，この評価結果に基づけば, 本ダンパーブレース構造では, 塑性率 $\mu$ が 2.5 を超える ような地震応答に対する減衰評価として, タイプ I 地震 動では $h_{e q}=20 \sim 30 \%$, タイプ II 地震動では $h_{e q}=15 \sim 20 \%$ と評価できる.

\section{6. 地震応答低減効果の検討}

\section{(1)座屈ブレ一ス組込み構造模型との比較}

ダンパーブレース組込み構造の応答低減効果と対比 させるために, 座屈ブレース組込み構造模型の地震态答 実験を行った. 座屈ブレース組込み構造模型に対しては, I-II-1 : 280Gal [L3 地震動]を入力したので, 同一の地震波 を入力した DB1 供試体の 2 回目の結果との比較を行った. この比較結果を図-18 に示す.

座屈ブレース組込み模型の座屈ブレース軸力一軸変 位関係より, L3 地震動に対しては, 座屈ブレースに座屈 が発生していることがわかる. ただし，3.(3)で示した座 屈ブレースの静的座屈軸力は $41 \mathrm{kN}(4.2 \mathrm{tf})$ であったが, 動 的実験における座屈軸力は $52 \mathrm{kN}(5.3 \mathrm{tf})$ と $20 \%$ 程度大き くなり, 動的な効果が現れているものと考えられる.

頂部加速度および応答変位の時刻歷では, 座屈ブレー スの座屈発生時点(図中にO印で示す点) 以降において, 座屈ブレースが圧縮側になる方向で(変位ではマイナス 側, 加速度ではプラス側), 忘答加速度はマイナス側に比 べて加速度が増加しなくなり, 応答変位についてはマイ ナス側に振動中心が移動し, 残留変位が生じている.

さらに, 頂部変位一ベースシャの履歷曲線から, 圧縮 側(マイナス側)についてはベースシャ $40 \mathrm{kN}$ で座屈が生 じるため, その荷重以上の増加はないが, 引張側(プラス 側)についてはその後も増加しており, 最大で $50 \mathrm{kN}$ 程度 のベースシャとなっている. それに比較して, ダンパー ブレース組込み構造では, ベースシャが最大でも $15 \mathrm{kN}$ 程度となっており, 震度法設計を施した座屈ブレ一ス組 込み構造と比べると，70\%程度のベースシャの低減効果
が現れていることがわかる.この結果より, 従来設計の ように弾性設計によって大きな地震力に抵抗しようと すると, ベースシャすなわち基礎への反力が過大になる 可能性があることがわかる. 一方, 頂部最大忘答変位は 座屈ブレース構造では $18 \mathrm{~mm}$ 程度であるのに対し, ダン パーブレース構造では $19 \mathrm{~mm}$ 程度と $4 \%$ 程度の増加とな っており, ベースシャの低減比率と比較すると, その増 加比率は小さい. これはダンパーブレース組込み構造に おけるエネルギー吸収効果が高いことを意味している.

\section{(2) 弾性応答との比較}

実際の震度法設計を施した試験体を用いた応答低減 効果は, 上記のように実験的に検証した. 次に, その他 の実験ケースについても, 弾性解析結果との比較を行い, 応答低减効果を検討した. 表-3に各地震入カレベルに対 する頂部応答加速度, 頂部応答变位の実験結果と弾性解 析結果の比較を示す. また図-19には, 表-3の結果を図 示したものを示す. 図-19 の横軸は各地震タイプ, 地震 動レベルを示し, 縦軸は実験結果の弾性解析結果に対す る比率, すなわち応答低減率を示している(○印). また, 参考までにダンパーブレース構造の応答值に対する座 屈ブレース構造の応答值の比率も口印で示す.

この結果より, 応答加速度については全体的に 50〜 $70 \%$ 程度の低减率となっており, 大きな応答低减効果を 示しているが, 入力地震レベルが増加するほど, その低 減率は大きくなる傾向にある. また, 応答変位について は, 全体的に弾性解析結果より増加寸る傾向を示してお り, 応答加速度とは逆に入力地震レベルが増加するほど, その増加率は大きくなる傾向を示している.

\section{(3) 地震応答低減要因に関する考察}

次に, これまでの結果を踏まえ, ダンパーブレース組 込み構造の応答低減の要因に関して検討した. ダンパー ブレースのような鋼材の弾塑性特性を利用した履歷減 衰要素を用いた構造においては, 次の $2 つ$ 要因が地震 応答低减に影響を及ぼしていると考えられる.

(1)減衰要素のエネルギー吸収能力による等価減衰の 増加

(2)減衰要素の塑性化に伴う等価剛性の低下(等価周期 の増加)

ここでは, これらの各要因による応答低减効果を, 応 答スペクトルを用いて定量的に評価した.ここでは, DB1 供試体の 2 回目の実験(I-II-1 : 280Gal, $\left.h_{e q}=24 \%\right)$ を例とし て採り挙げた.

図-20に入力地震波実測值を用いた加速度応答スペク トル，変位応答スペクトルを示す. 図-20 中には， 5.(1) の自由振動実験結果に基づき $h=2 \%$ としたダンパーブレ 一ス組込み構造の弾性構造としての応答スペクトル, お よび 5.(6)の考察を踏まえて $h=24 \%$ とした応答スペクト 


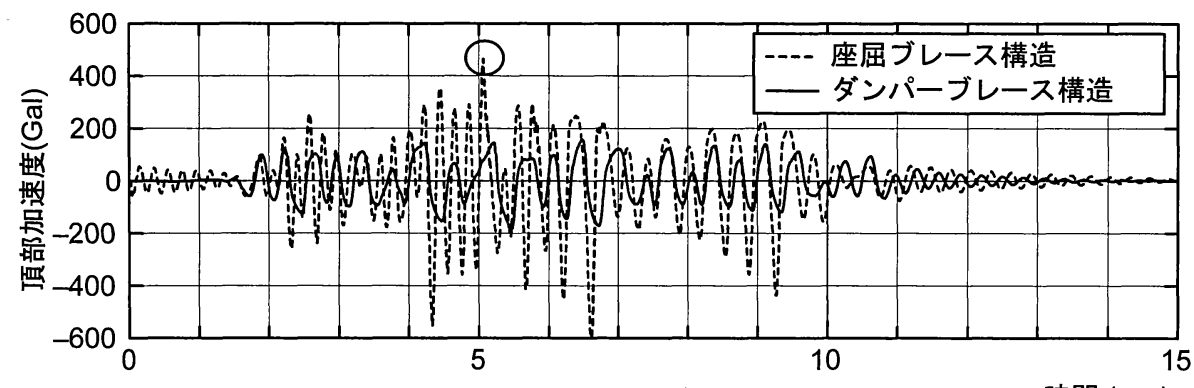

(a)頂部応答加速度の比較

時間 (sec)

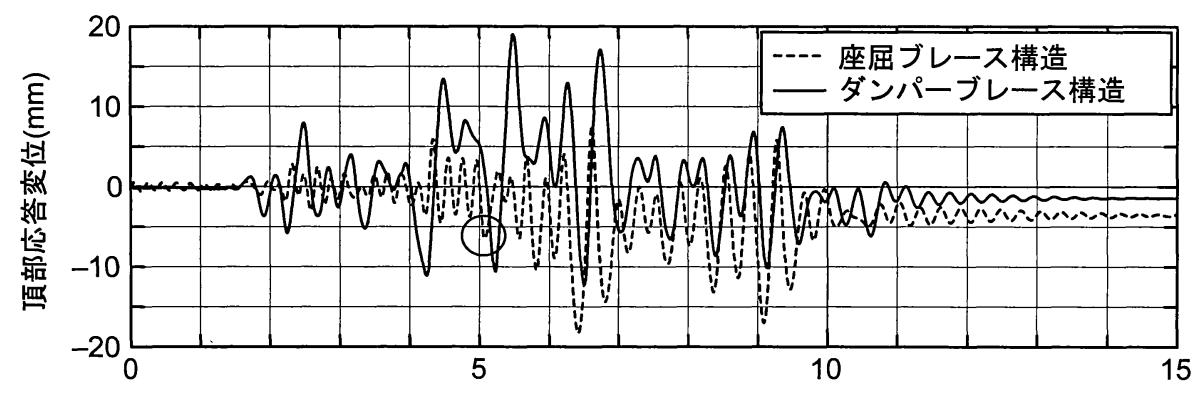

(b)頂部応答変位の比較

時間 (sec)

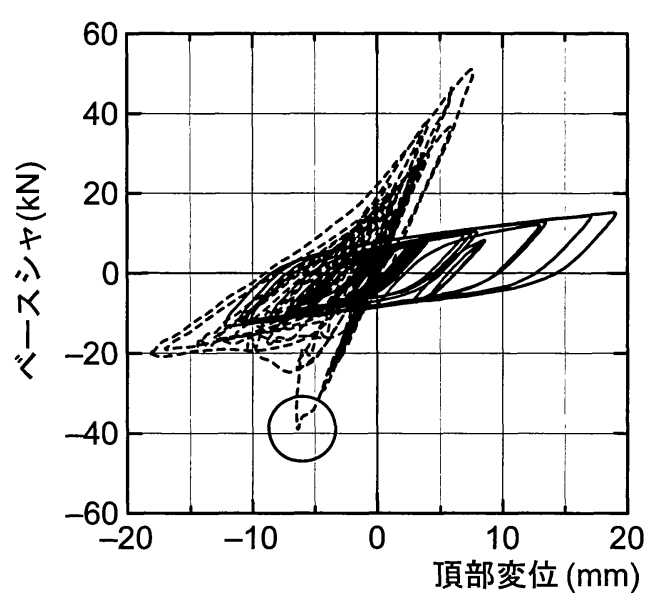

(c)頂部変位一ベースシャ関係の比較

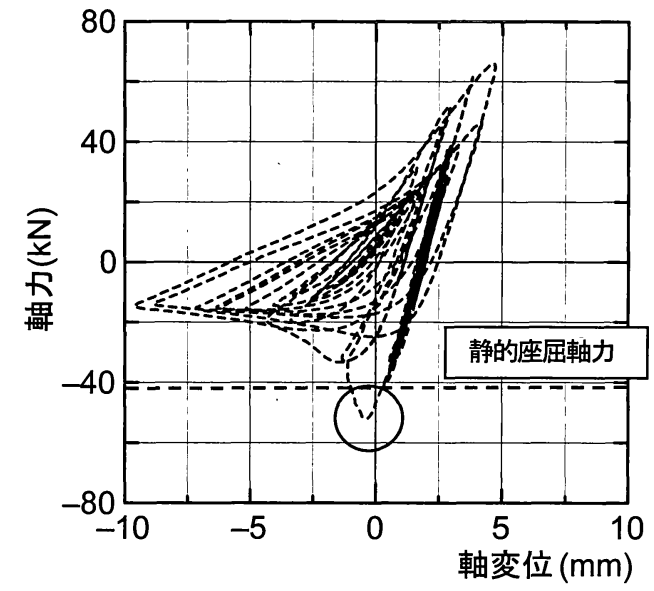

(d)座屈ブレースの履歴

図-18 座屈ブレース構造とダンパーブレース構造の地震応答比較

ルを示している. また，ダンパーブレース組込み構造で 弾性応答した場合の応答值を口印で，実験值を○印で示 す.この実験值に対応した等価周期は，5.(6)での等価剛 性より算定したものである. さらに，要因(2)のみが応答 に与える影響を評価するため, 上記の等価周期で弾性応 答した場合の応答值 $(h=2 \%$ の応答スペクトル上に乗る) をム印で示す.

この結果より，履歷減衰要素を用いた耐震構造では, その履歴減衰要素のエネルギ一吸収能力による等価減 衰の増加の効果, および履歴减衰要素の塑性化に伴う等 価周期の増加の効果により, 加速度応答スペクトルでは 両者の相乗効果で大きな応答低减が見られ，構造基部の
ベースシャは大幅に低减することがわかる．また，変位 応答スペクトルより，等価周期の増加に伴い，変位は大 きく増大するが, 等価减衰の増加により応答変位が低减 されるため, 過大な応答変位とはならないことがわかる.

これらの結果を踏まえると, 履歴减衰要素の降伏軸力 およひ岡性の調整, すなわち構造としての等価減衰と等 価周期の調整により，ベースシャを大きく低減させ，か つ応答変位の増加を抑えた領域を確保可能であること がわかる. この効果を最大限に発揮できるダンパーブレ 一ス特性が最適なダンパーブレースであると言える. た だし，ここでの結果は，本論文で用いたようなほぼ 1 自 由度系とみなせる構造における考察であるので, ア一チ 
表-3 弾性解析結果との比較

\begin{tabular}{|c|c|c|c|c|}
\hline $\begin{array}{l}\text { 地震 } \\
\text { タイプ }\end{array}$ & $\begin{array}{l}\text { 地震動 } \\
\text { レベル }\end{array}$ & & $\begin{array}{c}\text { 最大加速度 } \\
\left(\mathrm{cm} / \mathrm{s}^{2}\right)\end{array}$ & $\begin{array}{c}\text { 最大変位 } \\
(\mathrm{mm})\end{array}$ \\
\hline \multirow{9}{*}{ I } & \multirow{3}{*}{$\begin{array}{c}\text { L1地震動 } \\
(138 \mathrm{Gal})\end{array}$} & 弾性解析 & 317.5 & 6.58 \\
\hline & & 実験 & 131.2 & 6.71 \\
\hline & & 実験／解析 & $(0.41)$ & $(1.02)$ \\
\hline & \multirow{3}{*}{$\begin{array}{l}\text { L2地震動 } \\
(230 \mathrm{Gal})\end{array}$} & 弾性解析 & 595.9 & 12.45 \\
\hline & & 実験 & 176.1 & 15.78 \\
\hline & & 実験／解析 & $(0.30)$ & $(1.27)$ \\
\hline & \multirow{3}{*}{$\begin{array}{l}\text { L3地震動 } \\
(280 \mathrm{Gal})\end{array}$} & 弾性解析 & 648.2 & 13.52 \\
\hline & & 実験 & 181.3 & 19.02 \\
\hline & & 実験／解析 & $(0.28)$ & (1.41) \\
\hline \multirow{6}{*}{ II } & \multirow{3}{*}{$\begin{array}{c}\text { L1地震動 } \\
\text { (127Gal) }\end{array}$} & 弾性解析 & 295.6 & 6.13 \\
\hline & & 実験 & 133.4 & 6.14 \\
\hline & & 実験／解析 & $(0.45)$ & $(1.00)$ \\
\hline & \multirow{3}{*}{$\begin{array}{l}\text { L2地震動 } \\
\text { (200Gal) }\end{array}$} & 弾性解析 & 477.8 & 9.93 \\
\hline & & 実験 & 162.5 & 12.26 \\
\hline & & 実験／解析 & $(0.34)$ & $(1.23)$ \\
\hline
\end{tabular}

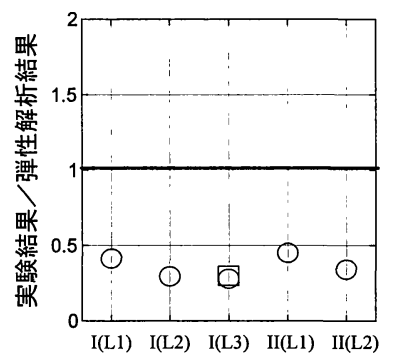

(a) 応答加速度

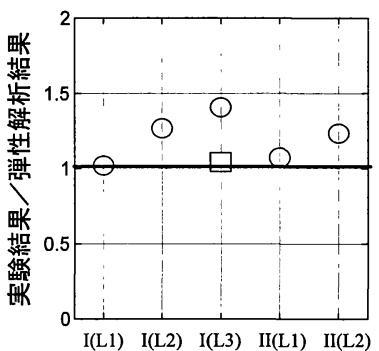

(b) 応答変位

図-19 応答低减率

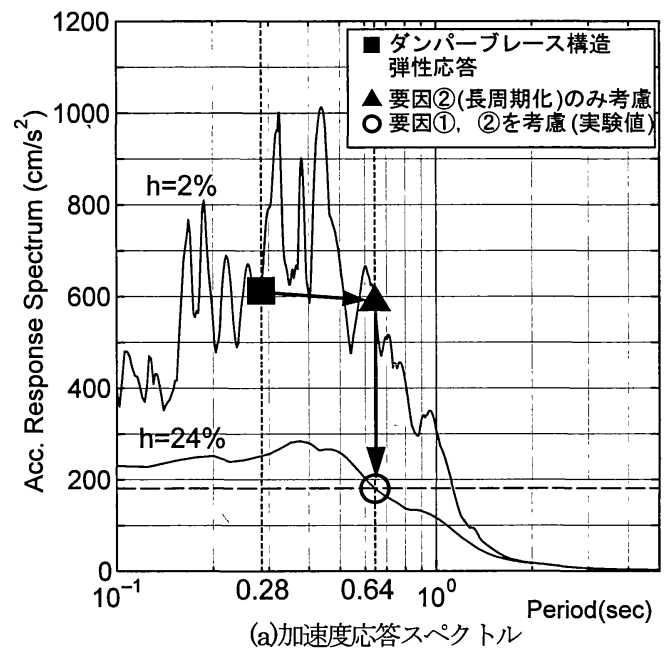

図-20 応答スペクトルによる応答低減効果の評価

橋のように幾つかのモードが連成する複雑な応答性状 を示す構造形式については，個々のモードの影響を考慮 した上で等価減衰, 応答低减率などの評価を行い ${ }^{18)}$, ダ ンパーブレースの最適な特性の設定, 配置に対する検討 を行うことが必要となる.

\section{7. まとめ}

本論文では，近年，構造物の地震応答低减対策として 着目されている制震ブレース(本研究においては両端軸 降伏座屈拘束型ダンパー組込み型ブレース “ダンパーブ レース”)をトラス斜材に挿入した橋梁トラス構造模型を 用いた地震応答実験を行い，ダンパーブレース組込み構 造の応答低減効果の実験的検証を行った. 結果をまとめ ると次のようである.

(1) 地震态答実験結果より, 橋梁に制震ブレース(ダンパ 一ブレース)を組込む耐震対策は，大きな地震忘答低 効果があることを実験的に確認，検証した.

(2) ダンパーブレース組込み模型と震度法(1 次設計)のみ を満足させた弾性設計模型(座屈ブレース模型)の実
験結果の比較より, 座屈ブレース模型では, 大地震時 にブレースが座屈して耐震性が確保できない結果と なったが, ダンパーブレース構造ではダンパーブレー スのエネルギー吸収効果により，ベースシャ(基部水 平反力)が大きく低減する効果が実験的に確認できた. 本実験では，ベースシャは 70\%低減し，一方，応答 変位は 4\%程度の増加に留まる結果が得られた。

(3) ダンパーブレース組込み模型の実験結果と弾性応答 解析結果の比較より, 応答加速度の応答低减率は 50 〜 70\%程度と大きく, 地震入力レベルの増加に伴い低 減率も増加する. ただし, 応答変位は弾性応答より増 加し, 地震入力レベルの増加に伴い増加率は大きくな る傾向を示した.

(4) タイプ I (海溝型), タイプII(直下型)地震動に対する 実験結果より, ダンパーブレース組込み構造は地震波 のタイプによらず, 安定したエネルギ一吸収性能を発 揮することを確認した. 本実験のようなトラス構造で は, 入力エネルギーの 85～95\%程度をダンパーブレ 一スの塑性エネルギーで吸収する結果となった。 
(5) 同一供試体に対して，地震入力レベル入力地震加速 度)を調整した地震動を複数回入力したが，大地震時 でも, 圧縮側, 引張側ともダンパーブレースの復元力 低下などは無く, 破断などの損傷も発生せず, 安定し た繰返し塑性変形特性を示した.

(6) ダンパーブレース組込み構造の減衰特性について，1 自由度系の等価線形解析の概念を用いた等価減衰評 価を行った結果, 入力地震タイプによってばらつきは あるが, ダンパーブレース組込み構造としての塑性率 $\mu$ が 2.5 を超えるような地震応答に対しては, タイプ I 地震動で等価減衰 $h_{e q}=20 \sim 30 \%$ 程度, タイプ II 地震 動で $h_{e q}=15 \sim 20 \%$ 程度となった。

\section{参考文献}

1）野中哲也, 宇佐美勉, 吉野広一, 坂本佳子, 鳥越卓志: 上 路式アーチ橋の大地震時弹塑性挙動およひ洏震性向上に関 する研究，土木学会論文集，No.731/I-63，pp.31-49， 2003.

2）野中哲也，宇佐美勉，坂本佳子，岩村真樹 : 上路式鋼卜ラ ス橋の大地震時弾塑性挙動および洏震性向上に関する研究, 構造工学論文集, Vol.49A, pp.531-542, 2003.

3）金治英貞, 北沢正彦, 鈴木直人 : 長大ゲルバートラス橋の 而震補強に関する地震応答解析と損傷制御設計，土木学会 既設構造物の而震補強に関するシンポジウム, pp.107-114, 2002.

4）土木学会地震工学委員会・既設構造物の耐震補強に関する 研究小委員会:既設構造物の耐震補強に関する研究報告書, 2002.

5) Seim, C. etal. : Toll Bridge Seismic Safety Review-Final Report to the Caltrans Director, Engineering Service Center, the Consultant Contact Management Branch and the Division of Structures, 1999.

6) 和田 章, 岩田 衛, 清水敬三, 安部重孝, 川合廣樹 : 建筑 物の損傷制御設計，丸善株式会社，1998.

7) 日本鋼構造協会 鋼材俱楽部 : 履歷型ダンパー付骨組の地 震応答性状と而震設計法, 1998.

8）岡 俊蔵, 増田伊知郎, 古川謙一郎, 井上幸一, 明神久也： 各種ダンパを適用した鋼橋の耐震性向上法, 第 5 回 而震補
強・補修技術，而震診断技術に関するシンポジウム講演会 論文集, pp.31-38, 2001.

9）井上幸一, 明神久也, 増田伊知郎，中出 收: 軸力降伏型鋼 製ダンパを適用した鋼橋の耐震性向上法，第 5 回地震時保 有水平耐力法に基づく橋梁の耐震設計に関するシンポジウ ム講演論文集, pp.43-50, 2002.

10) 上平 悟, 中出 收, 井上幸一, 明神久也, 森下邦宏 : 長大 橋の耐震性向上方法, 三菱重工技報, 第 39 巻, 第 6 号, pp.312 $-315,2002$.

11）四條利久磨，森下邦宏，川島一彦，浦辻和幸，田中昭人： ダンパーブレースによる新王渡橋(仮称)の耐震性向上, 土木 学会 第 58 回年次学術講演会講演概要集, pp.65-66, 2003.

12）村瀬良秀，森下邦宏，井上一朗，立山英二：両端に軸降伏 ダンパーを組込んだ長尺ブレースの座屈拘束条件(その1) 設計法, (その 2$)$ 模型実験, 平成 11 年度建築学会近畿支部 研究報告集, pp.293-300, 1999.

13) 森下邦宏, 村瀬良秀, 井上一朗, 立山英二 : 両端に軸降伏 ダンパーを組込んだ長尺ブレースのダンパー部復元力特性 試験，2000 年度日本建築学会大会学術講演梗概集，pp.903 $-904,2000$.

14) 江守一郎 : 模型実験の理論と応用, 技報堂出版, 1994.

15) 山田 哲, 山口路夫, 竹内百合, 竹内 徹, 和田 章 : 動的繰 り返し載荷実験結果に基づくダンパー用鋼材の履歷特性の 評価(速度依存性を考慮したダンパー用鋼材の履歷特性に 関する研究 その 1$)$, 日本建築学会構造系論文集, 第 553 号, pp.121-128, 2002.

16) 日本道路協会: 道路橋示方書・同解説 V 而震設計編, 2002.

17) 柴田明徳: 最新 而震構造解析, 森北出版, 1991.

18) 福田智之, 川島一彦, 渡辺学歩 : ブレースダンパーによる 鋼製ア一于橋の地震応答低減効果, 第 7 回地震時保有水平 而力法に基づく橋梁等構造の耐震設計に関するシンポジウ 厶講演論文集，pp.243-250，2004.

19) 本田誠, 森下邦宏, 井上幸一, 平井潤, 阿比留久徳 : 履歴 型制震デバイス組込み構造の而震性向上に関する解析的検 討, 構造工学論文集, Vol.50A, pp.539-550， 2004.

(2003.11. 10 受付)

\title{
EXPERIMENTAL VERIFICATION ON THE EFFECTIVENESS OF DAMPER BRACES FOR REDUCING RESPONSE OF A STEEL MODEL BRIDGE
}

\author{
Kunihiro MORISHITA, Koichi INOUE, Kazuhiko KAWASHIMA, \\ Hisanori ABIRU, Jun HIRAI and Makoto HONDA
}

\footnotetext{
The authors have already investigated the structural performance of the energy-dissipating structural system with hysteresis braces (Damper Brace) by analyses and verified the hysteresis properties of Damper Brace by experiments. However for implementing the systems to bridges, it is important to verify the effect of reducing structural response under a ground motion. In this paper, seismic response tests were conducted with a scaled model of abutment structure in which Damper Braces were installed. As a result, it was confirmed that the seismic response of the model reduced significantly comparing to the standard structure without Damper Braces and that the Damper Braces had good energy dissipation during the excitation.
} 